\title{
Type of pests in agrobiocenosis of rice and pest control
}

\author{
$N$ Otamirzayev ${ }^{1, *}$ and $R$ Ibodullayeva ${ }^{2}$ \\ ${ }^{1}$ Tashkent State Agrarian University, Universitetskaya str., 2, 100140, Tashkent, \\ ${ }^{2}$ Rice Research Institute, Tashkent, Uzbekistan
}

\begin{abstract}
In the article, 10 species of pests that damage rice plants during the season in the rice agrobiocenosis were identified. Leptestheria dahalacensis Sars, Apus concriformis Sh., Corn stalk Ostrinia nubilalis $\mathrm{Hb}$, and Cephus pygmaeus have been reported to cause damage to rice grasses.A growth calendar has been developed. In the pest experiment during the rice germination period, biological effectiveness of the drug was the highest for 15 days, accounted for $93.9 \%$, in the variant treated with Nurell D 55\% em.k at rate of $1.5 \mathrm{l} / \mathrm{ha}$. When the variant was treated with Tayshin 500 s.d.g (Clothianidin) at rate of $0.06 \mathrm{~kg} / \mathrm{ha}$, the effectives of the drug were $93.3 \%$ in 14 days. In the experiment, Nurell D 55\% em.k (1.5 1/ha) was used against the main pests $(0.06 \mathrm{~kg} / \mathrm{ha})$ yielded $70.7 \mathrm{q} / \mathrm{ha}$ in the variant in which the chemical agent was used, and 10.1 additional yields were reported. The results showed that the yield of "Iskandar" variety was $73.8 \mathrm{q} / \mathrm{ha}$, which was $13.2 \mathrm{q} /$ ha more than the control, when Nurell D 55\% em.k (1.5 1/ha) against the main pests was applied. Whereas new chemical Tayshin 500 s.d.g. $(0.06 \mathrm{~kg} / \mathrm{ha})$ was used in the variant, in which the yield was $70.7 \mathrm{q} / \mathrm{ha}$, and it was more by $10.1 \mathrm{q} / \mathrm{ha}$ than the control variant.
\end{abstract}

\section{Introduction}

Rice is one of the oldest crops in the world and a staple food for a third of the world's population. In 2018, rice was planted on 155 million hectares, accounted for 765.6 million tons of the rice harvest. In our country, rice was planted on 115,000 hectares, and the gross harvest was 450,000 tons $[1,3-5,7]$. This amount is enough to meet the growing demand of the country's population for rice, which is one of the main food products. According to official data, about 35,000 tons of rice products have been imported in recent years to fully meet the needs of the population. Therefore, it is important to reduce rice imports, increase rice yields, and accelerate rice cultivation using modern methods to meet the population's demand for rice and rice products, including research to protect rice from various pests. As a result of the reforms carried out in agriculture in this regard in our country, a wide range of measures are being taken to increase the production of cereals, in particular rice and rice [9-11, 15]. In particular, the presidential decree No. 5303 of the Republic of Uzbekistan on

\footnotetext{
*Corresponding author: n.g.otamirzayev@yandex.com
} 
"Measures to ensure further food security of the country" on January 162018 and decree of the Cabinet of Ministers No.259 of the Republic of Uzbekistan on "Rational placement of agriculture crops" on March 292019 were issued [1, 2]. For the further development of rice in the country, it is necessary to clarify the structure of species of coniferous insects living in the rice ecosystem, to identify the dominant species, to study the dynamics of their development, the degree of damage to pests and the criterion of economic damage and to create a harmonized system of protection against these pests on the basis $[7,8]$.

In the soil-climatic conditions of the country in the 30-90s of the 20th century on the pests of rice and their control, (agrotechnical, biological, chemical) V.P. Shagaev (19371938), V.S. Chuvakhin (1929), VV Yakhontov (1957), MP Sborshchikova (1970), AA Shokirov (1998) conducted research in Uzbekistan. At that time, rice was mechanized, the effects of pests in the germination phase were insignificant, and the chemicals recommended for pest control in the germination phase of rice were out of production due to their negative impact on the environment and their obsolescence. Recent scientific studies have shown that insecticides have strong collateral effects on humans as well as pests [14-17].For example, pest control affects only the environment, biodiversity, and human health. The high incidence of pest-related incidents in recent years has been acknowledged by many scientists to be probably due to changes in climate and cropping systems in modern rice cultivation $[12,18]$. The fact that the main goal is to cultivate only high rice yields, which is often associated with overuse of fertilizers and pesticides, which in turn leads to a decrease in biodiversity and natural biological control. As a result, drinking water in rivers is highly polluted with pesticides and agricultural products are poisoned. The rapid and high level of resistance of some pests to insecticides can lead to many negative environmental consequences, such as an epidemic of secondary pests, environmental pollution and disturbance of the ecological balance [19]. These serious adverse effects damage the ecosystem, often leading to pest epiphytosis and in turn increasing pesticide consumption, resulting in the formation of circles. Excessive use of pesticides is a major barrier to sustainable agriculture in China and poses a threat to food security and human health [20-22].

The objective of the research was to clarify the species composition of arthropods living in the rice ecosystem, to study the dynamics of their development, the degree of pest damage and economic damage criteria, and to improve the means and methods that can provide protection against pests during storage and processing.

\section{Materials and methods}

The research was conducted in the experimental fields of the Rice Research Institute on 12 cards and 2 edges. The institute is located in the southeastern part of Tashkent region, in the Chirchik oasis, $15 \mathrm{~km}$ from Tashkent, on the left bank of the Chirchik River in Uzbekistan. Tashkent region is located in the eastern part of Uzbekistan and covers an area of $15,600 \mathrm{~km}^{2}$, or $10 \%$ of the country's territory. It is bordered by the Republic of Tajikistan to the south, Kazakhstan to the northwest, Kyrgyzstan to the northeast, Namangan Province to the east, and Syrdarya Province to the southwest.

\subsection{Climatic conditions}

The natural climate of Tashkent region is sharply continental and arid, rich in heat and sunlight throughout the year. Sunny days are on average of 295-390 hours during the summer months. This allows to easily plant and harvest rice. Tashkent region are hot and 
dry in the summer. July is the hottest month. The growth and development of agricultural crops certainly depends on air temperature. The annual rainfall is $432-377 \mathrm{~mm}$.

\subsection{Soil conditions}

The soil of the experimental area is non-saline, moderate (PN-7.24), meadow-swamp soils. The amount of physical mud in the driving layer is $40-60 \%$. Humus in the driving layer $(0-$ $30 \mathrm{~cm}$ ) in the experimental field is $1.97 \%$, mobile nitrogen $23.5 \mathrm{mg} / \mathrm{kg}$, mobile phosphorus $109 \mathrm{mg} / \mathrm{kg}$, mobile potassium $27.5 \mathrm{mg} / \mathrm{kg}[9,10]$.

Samples were collected from the experimental fields to study the species composition of the insects and their distribution area. The types of samples obtained were stored in fixators made from a mixture of $5 \%$ formalin or $70 \%$ alcohol and $4 \%$ glycerin until determined using systematic experts. To determine the presence of pests, rice was examined in two phonological terms [5]. After the appearance of the grass, it was determined to what extent the crop was infested by pests of the crop - rice thistle, crustaceans, rice flies, barley minaret, shore mosquito larvae. In this case, the observations were made on a sample area with eight frames (frame lysimetric) measuring $25 \times 25 \times 30 \mathrm{~cm}$ per hectare. At the end of the rice ginning and during the ginning period, re-monitoring was carried out by separating the sample plots in the same areas. The stalks were separated from the rice stalks by areas affected by the corn moth, and it was determined how many larvae were present in them [7$9,13]$. A logarithmic scale was used to determine the number (density) of the pest in a bush and the population density in the rice field. Their density was determined using the following equation [4]:

$$
\mathrm{S}=(\mathrm{LC}) / \mathrm{T},
$$

where: $\mathrm{S}$ is the number of pests;

$\mathrm{L}$ is the degree of damage to the crops (in points);

$\mathrm{C}$ is the number of plants affected at that point;

$\mathrm{T}$ is the number of plants in the sample.

In the study of the biological efficacy of pesticides in rice, insect counting in small, field and production experiments was carried out in 1, 3, 7 and 14 days before and after treatment. The effectiveness of chemical and biological agents was calculated using the Abbot equation $[6,7,11]$ :

$$
\mathrm{BS}=100\left(\mathrm{~A}_{\mathrm{v}}-\mathrm{V}_{\mathrm{a}}\right) / \mathrm{A}_{\mathrm{v}},
$$

where:

BS - biological efficiency, $\%$;

$\mathrm{A}$ is the number of pests before spraying in the experiment;

$\mathrm{a}$ is the number of pests after spraying in the experiment;

$\mathrm{V}$ is the number of pests before spraying in the control variant;

$\mathrm{v}$ is the number of days after spraying in the control of pests.

The agro-technical and chemical (chemical) methods of rice pest control were carried out based on the following experimental system. Areas of not less than $100 \mathrm{~m}^{2}$ were set aside for small field experiments. Each variant of our study was conducted in four returns. The experiments were carried out based on "Methods of conducting field experiments" developed by N.Sh. Nurmatov [5]. In the research, test was performed using the following modern pesticides at different consumption rates during rice germination. 
5. Variant -Nurell-D 55\% em.k (Cypermethrin + chlorpriphos) -1.5 1/ha.

4. Variant-Tayshin 500 s.d.g (Clothianidin) $-0.06 \mathrm{~kg} / \mathrm{ha}$

3. Variant - Atilla $5 \%$ em.k (Lambda-cyhalotrin) $-0.51 /$ ha

2. Variant-sample (Fufanon 57 em.k (Malation) 1.0 1/ha)

1. Variant-control

In the experiment, a new generation of insecticides against pests that cause damage during the germination phase of rice was tested at different consumption rates (Figure 1). Processing was carried out using a motorized hand apparatus at the expense of 200 liters of water consumption per hectare. In the study, entomological controls were performed for 14 days before and after spraying.

\section{Results and discussion}

The results showed that samples of 10 species of worthy harmful insects and other Staphylococcus aureus in the rice plant was found. During the germination and mowing phases in the experimental fields planted with rice variety "Iskandar", bokovlav crab (Leptestheria dahalacensis Sars) and shale crab (Apus concriformis Schaff) were observed. In the period of rice growth, European wheat stem sawfly (Cephus pygmaeus) and corn moth (Ostrinia nubilalis $\mathrm{Hb}$.) were mostly identified pests. According to the experiment, bokovlav crab (Leptestheria dahalacensis Sars) and shale crab (Apus concriformis Schaff) were appeared when the field of rice was flooded with water, and the number of the pests was increased between the end of May and early June, after cultivation of rice. The results showed that there were 62 pieces of Bokovlav crap (Leptestheria dahalacensis Sars), 2 pieces of rice whorl maggot (Hydrellia griseola Fall), 48 pieces of coastal mosquito larvae, 1 piece of rice water weevil (Hydronomus sinuaticollis Faust), 10 pieces of European maize borer, and 8 pieces of wheat stem sawfly (Cephus pygmaeus) in $1 \mathrm{~m}^{2}$ land (Table 1).

Table 1. Rate of occurrence of pests in the experimental field (Tashkent region, Urtachirchik district, 2020).

\begin{tabular}{|c|c|c|c|c|}
\hline$\#$ & Name of pests & Name in science & $\begin{array}{c}\text { Number of 1 m² } \\
\text { area, pcs }\end{array}$ & $\begin{array}{c}\text { Number of pests on } \\
\text { 1 stem, pcs }\end{array}$ \\
\hline 1 & Shield crap & Apus concriformis Schaff & 18 & - \\
\hline 2 & Bokovlav crap & $\begin{array}{c}\text { Leptestheria dahalacensis } \\
\text { Sars }\end{array}$ & 62 & $2 / 0.5$ \\
\hline 3 & $\begin{array}{c}\text { Rice whorl } \\
\text { maggot }\end{array}$ & Hydrellia griseola Fall & - & 48 \\
\hline 4 & $\begin{array}{c}\text { Coastal } \\
\text { mosquito larvae }\end{array}$ & Ephydra macellaria Egger & - & - \\
\hline 5 & $\begin{array}{c}\text { Rice Water } \\
\text { Weevil }\end{array}$ & $\begin{array}{c}\text { Hydronomus sinuaticollis } \\
\text { Faust }\end{array}$ & 1 & 10 \\
\hline 6 & $\begin{array}{c}\text { European maize } \\
\text { borer }\end{array}$ & Ostrinia nubilalis Hb & - & - \\
\hline 7 & $\begin{array}{c}\text { Mole cricket } \\
\text { Gryllotalpa unispina } \text { Saus }\end{array}$ & 0.3 & 7 \\
\hline 9 & Rice locust & Exyafuscvoitata Marsch & 1 & 9 \\
\hline 10 & $\begin{array}{c}\text { European wheat } \\
\text { stem sawfly }\end{array}$ & Cephus pygmaeus & - & - \\
\hline
\end{tabular}

Note: $2 / 0.5$ is rice whorl maggot in two stems of rice. 
The results of the experiment showed that the number of bokoplav crap was in between 61.3-64.6 pieces in $1 \mathrm{~m}^{2}$, and after applying chemical drugs, it was decreased steadily except the control variant. Furthermore, it was observed that biological efficiency was also decreased. During the last calculation day (14) it was found that high, satisfactory results were obtained in almost all variants, and biological efficiency was 92.8-93.9\%. When Fufanon $57 \%$ em.k. (1.0 1/ha) was used in the variant against bokovlav crab (Leptestheria dahalacensis Sars), the biological efficiency was $89.9 \%$ on 14 days of treatment (Fig. 1).

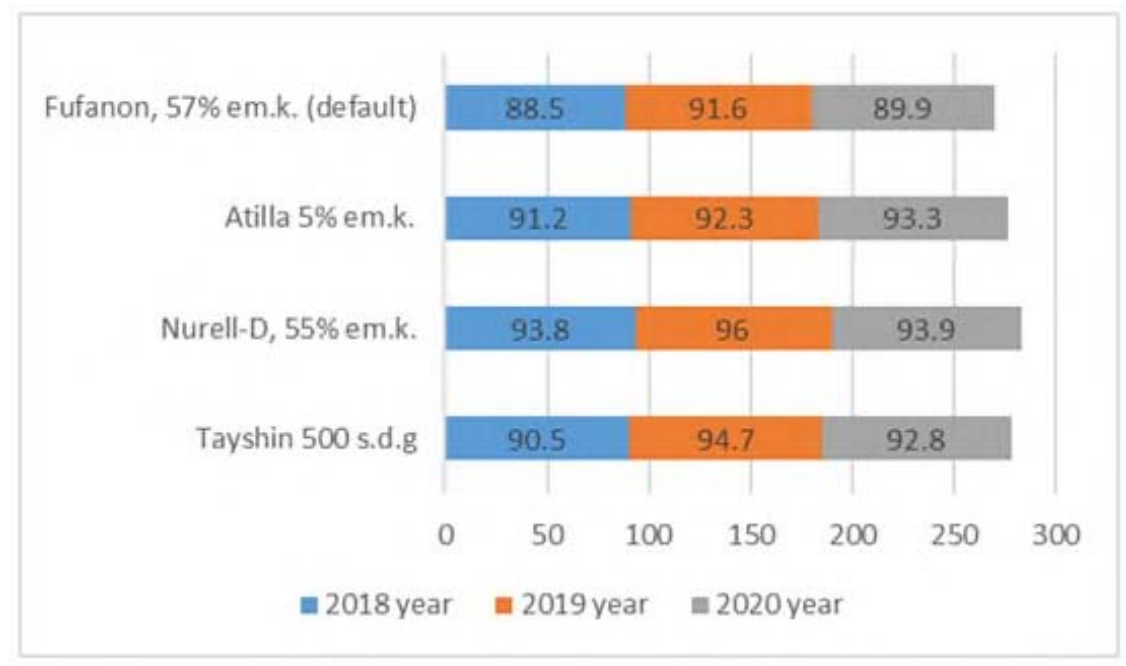

Fig. 1. Biological efficacy of chemicals used against bakoplav crap ((Leptestheria dahalacensis Sars), $\%$.

The biological efficiency was $92.8 \%$ in the variant treated with Tayshin 500 s.d.g (Clothianidin) at rate of $0.06 \mathrm{~kg} / \mathrm{ha}$ during 14 days. Furthermore, Nurell D 55\% em.k. at rate of $1.5 \mathrm{l} / \mathrm{ha}$ was applied in the variant, accordingly, the biological efficiency reached the highest results in 14 days, accounted for $93.9 \%$ (Table 2).

Of the chemicals used against shrimp during the germination period of rice, Fufanon, $57 \%$ em.k. (1.0 1/ha) was used as a standard and its biological efficiency was $89.8 \%$ after 14 days, and in the variant treated with Tayshin 500 s.d.g (Clothianidin) at $0.06 \mathrm{~kg} / \mathrm{ha}$, it was $91.6 \%$ in 14 days. Moreover, this figure was $90.4 \%$ in the variant, which was treated with Atilla 5\% em.k (Lambda-cyhalotrin) at rate of $0.5 \mathrm{l} / \mathrm{ha}$, whereas the biological efficiency was $93.1 \%$ in 14 days when Nurell-D 55\% em.k (Cypermethrin + chlorpriphos) at 51 /ha was applied (Table 2).

Several factors influenced the yield of rice, not one. High yields of all crops, including rice, also was depend on successful pest control. At the end of the season, the experiments were carried out by sampling on the methods, harvesting, biometric analysis and determining the yield. According to the results of a 3-year study, the non-pest control option, in the rice field, the yield was $51.0 \mathrm{q} / \mathrm{ha}$ in $2018,53.6 \mathrm{q} / \mathrm{ha}$ in 2019 , and $60.6 \mathrm{q} / \mathrm{ha}$ in 2020. In the study, Fufanone was used as a benchmark in the 1.0 -liter version of $57 \%$ em.c. per hectare. Evidently, an average of $59.1 \mathrm{q} /$ ha harvest in 2018, $58.6 \mathrm{q} /$ ha harvest in 2019, and $68.4 \mathrm{q} /$ ha harvest in 2020 was obtained. 
Table 2. Biological efficacy of chemicals used against Apus concriformis Schaff (Tashkent region, Ortachirchik district, experimental area 2020).

\begin{tabular}{|c|c|c|c|c|c|c|c|}
\hline \multirow{3}{*}{ \# } & \multirow{3}{*}{ Variants } & \multirow{3}{*}{$\begin{array}{c}\text { Consumption } \\
\text { rate of the } \\
\text { drug, l/ha, } \\
\mathrm{kg} / \mathrm{ha}\end{array}$} & \multicolumn{4}{|c|}{$\begin{array}{l}\text { The average number of shielded } \\
\text { crap per } 1 \mathrm{~m}^{2}\end{array}$} & \multirow{3}{*}{$\begin{array}{c}\begin{array}{c}\text { Efficiency, } \\
\% \text { days }\end{array} \\
14\end{array}$} \\
\hline & & & \multirow{2}{*}{$\begin{array}{c}\text { Until } \\
\text { processing }\end{array}$} & \multicolumn{3}{|c|}{$\begin{array}{c}\text { In the days after } \\
\text { processing }\end{array}$} & \\
\hline & & & & 3 & 7 & 14 & \\
\hline 5 & Nurell-D, 55\% em.k. & 1.5 & 15.3 & 6.0 & 3.0 & 1.7 & 93.1 \\
\hline 4 & Tayshin 500 s.d.g & 0.06 & 14.7 & 6.0 & 3.0 & 2.0 & 91.6 \\
\hline 3 & Atilla 5\% em.k. & 0.5 & 16.7 & 6.3 & 4.0 & 2.6 & 90.4 \\
\hline 2 & $\begin{array}{l}\text { Fufanon, } 57 \% \text { em.k. } \\
\text { (standard) }\end{array}$ & 1.0 & 20.0 & 8.3 & 5.6 & 3.3 & 89.8 \\
\hline 1 & Control (unprocessed) & - & 16.7 & 18.3 & 22.0 & 27.0 & \\
\hline
\end{tabular}

In the study (Table 2), the average yield of rice in the "Iskandar" variety using pesticides (Nurell D 55\% em.k. 1.5 1/ha) was $71.1 \mathrm{q} / \mathrm{ha}$ in 2018, $70.2 \mathrm{q} / \mathrm{ha}$ in 2019 , and 73.8 $\mathrm{q} / \mathrm{ha}$ in 2020 . It can be seen that due to the high pest efficiency of this chemical agent, an additional yield of $13.2 \mathrm{q} / \mathrm{ha}$ was achieved in 2020 compared to the control. Through using chemical drug, Tayshin 500 s.d.g. $(0.06 \mathrm{~kg} / \mathrm{ha})$ in 2020 it was possible to get $70.7 \mathrm{q} / \mathrm{ha}$, which was $10.1 \mathrm{q} /$ ha more than the initial stage.

\section{Conclusions}

During the experiment, 10 species of worthy harmful insects and other Staphylococcus aureus in the rice plant was found. During the germination and mowing phases in the experimental fields planted with rice variety "Iskandar", bokovlav crab (Leptestheria dahalacensis Sars) and shale crab (Apus concriformis Schaff) were observed. In the period of rice growth, European wheat stem sawfly (Cephus pygmaeus) and corn moth (Ostrinia nubilalis $H b$.) were mostly identified pests. According to the experiment, bokovlav crab (Leptestheria dahalacensis Sars) and shale crab (Apus concriformis Schaff) were appeared when the field of rice was flooded with water, and the number of the pests was increased between the end of May and early June, after cultivation of rice.

At the end of the season, the experiments were carried out by sampling on the methods, harvesting, biometric analysis and determining the yield. According to the results of a 3year study, the non-pest control option, in the rice field, the yield was $51.0 \mathrm{q} / \mathrm{ha}$ in 2018 , $53.6 \mathrm{q} / \mathrm{ha}$ in 2019 , and $60.6 \mathrm{q} / \mathrm{ha}$ in 2020 . In the study, Fufanone was used as a benchmark in the 1.0-liter version of $57 \%$ em.c. per hectare. Evidently, an average of $59.1 \mathrm{q} / \mathrm{ha}$ harvest in $2018,58.6 \mathrm{q} /$ ha harvest in 2019 , and $68.4 \mathrm{q} /$ ha harvest in 2020 was obtained. In the study, the average yield of rice in the "Iskandar" variety using pesticides (Nurell D 55\% em.k. $1.5 \mathrm{l} / \mathrm{ha}$ ) was $71.1 \mathrm{q} / \mathrm{ha}$ in $2018,70.2 \mathrm{q} / \mathrm{ha}$ in 2019 , and $73.8 \mathrm{q} / \mathrm{ha}$ in 2020 .

\section{References}

1. N. Teshaev, B. Mamadaliyev, A. Ibragimov, S. Khasanov, InterCarto. InterGIS, 26(3), 324-333 (2020)

2. A. Jumanov, S. Khasanov, A. Tabayev, G. Goziev, U. Uzbekov, E. Malikov, In IOP Conference Series: Earth and Environmental Science, 614(1), 012150 (2020) 
3. M. Aktar, D. Sengupta, A. Chowdhury, Interdisciplinary toxicology, 2, 1 (2009)

4. R. Kulmatov, A. Taylakov, S. Khasanov, Environmental Science and Pollution Research, 28(10), 12245-12255 (2021)

5. M. Bari, N. Ahmed, S. Haque, M. Rabbi, K. Iftekharuddaula, Bangladesh Rice Journal, 19, 1 (2015)

6. M. Bux, M. Khan, N. Ahmad, M. Tofique, M. Ismail, Pak. J. Agri., 29, (2013)

7. S. Parajuli, J. Shrestha, S. Ghimire, Archives of Agriculture and Environmental Science, 5, 2 (2020)

8. Y. Peng, F. Li, N. Xu, R. Kulmatov, K. Gao, G. Wang, Y. Zhang, Y. Qiao, Y. Li, H. Yang, S. Hao, Q. Li, S. Khasanov, Chinese Journal of Eco-Agriculture, 29(2), 312-324 (2021)

9. I. Aslanov, S. Khasanov, Y. Khudaybergenov, M. Groll, Ch. Opp, F. Li, E. Ramirez Del-Valle, In E3S Web of Conferences, 227, 02005 (2021)

10. W. Zhang, C. Yan, M. Li, L. Yang, B. Ma, H. Meng, J. Chen, Journal of agricultural and food chemistry, 65, 6 (2017)

11. X. Wang, G. Wang, Z. Zhu, Q. Tang, Y. Hu, F. Qiao, J. Cheng, Pest management science, 73, 6 (2017)

12. S. Isaev, S. Khasanov, Y. Ashirov, A. Gofirov, T. Karabaeva, In E3S Web of Conferences, 244, 02047 (2021) 